\title{
Volatilization of Aluminum Oxycarbides and of Alumina with Carbon in Reduction of Alumina
}

\author{
By Harumi Yokokawa*, Masao Fujishige*, Seiichi Ujiie*, \\ Tetsuya Kameyama*, Masayuki Dokiya* and Kenzo Fukuda*
}

\begin{abstract}
The volatilization in the $\mathrm{Al}-\mathrm{O}-\mathrm{C}(-\mathrm{Si}-\mathrm{Fe})$ system have been investigated mainly by thermal gravimetry in vacuum for four cases; (1) aluminum oxycarbides, (2) mixtures of alumina and carbon with and without additives (iron oxide, silicon nitride and silicon carbide), (3) mixtures of alumina and aluminum carbide or silicon carbide and (4) mixtures of alumina, silica (mullite), iron oxide and carbon. $\mathrm{Al}_{2} \mathrm{OC}$ evaporated essentially congruently, whereas $\mathrm{Al}_{4} \mathrm{O}_{4} \mathrm{C}$ evaporated incongruently; $\alpha-\mathrm{Al}_{2} \mathrm{O}_{3}$ was formed in addition to vapors. The volatilization reaction between alumina and carbon was found to be enhanced remarkably when iron was added, unchanged by SiC addition and prevented slightly in the presence of $\mathrm{Si}_{3} \mathrm{~N}_{4}$. The mixtures of alumina and carbide volatilized at lower temperatures than did those of alumina and carbon. These features are discussed in terms of the equilibrium pressure in the light of previous results of reaction experiments focussed upon the oxycarbide formation.
\end{abstract}

(Received August 24, 1983)

Keywords: volatilization, evaporation, aluminum oxycarbide, thermal analysis, reduction, alumina, carbon

\section{Introduction}

In reduction of alumina with carbon, the following features make it quite difficult to produce aluminum in industrial furnaces ${ }^{(1)(2)}$ :

(1) Volatilization ${ }^{\dagger}$; aluminum suboxide vapor, $\mathrm{Al}_{2} \mathrm{O}$, in addition to $\mathrm{Al}(\mathrm{g})$ becomes relatively stable at high temperatures.

(2) Formation of oxycarbides; the aluminum oxycarbides, $\mathrm{Al}_{4} \mathrm{O}_{4} \mathrm{C}$ and $\mathrm{Al}_{2} \mathrm{OC}$, as well as $\mathrm{Al}_{4} \mathrm{C}_{3}$ are formed and may make complicated the reaction path to the metal production.

(3) High solubility of carbon in liquid aluminum metal at high temperatures.

In recent years, we have been making efforts in establishing an aluminum blast furnace process $^{(2)(4)}$. In due cource ${ }^{(4)}$, we have come to know that the crucial points of making such process feasible will be as follows:

(1) Lowering the volatilization of aluminum component to avoid the bridge formation and to obtain a high aluminum yield;

(2) Maintaining the fluidity of the produced metals and of the unreduced oxide/carbide melts in the vicinity of the furnace hearth;

* National Chemical Laboratory for Industry, Tsukuba, Ibaraki 305, Japan.
(3) Protecting the produced metals from being reoxidized in the vicinity of the race way.

In view of the first point, it becomes quite important to investigate the evaporation ${ }^{\dagger}$ of aluminum oxycarbides and the volatilization reaction ${ }^{\dagger}$ of alumina with carbon. It is well known in patent documents ${ }^{(5)(6)}$ that $\mathrm{Al}_{4} \mathrm{O}_{4} \mathrm{C}$ is volatile, whereas $\mathrm{Al}_{2} \mathrm{OC}$ is less volatile. However, we need more detailed knowledge to foresee the high temperature behavior of aluminum compounds in a blast furnace. There are unfortunately few reports on such behaviors.

In a previous report ${ }^{(2)}$ (referred to as $I$ in this paper), we reported experimental results on the reaction of alumina with carbon in the presence of silicon compounds $\left(\mathrm{SiO}_{2}, \mathrm{SiC}\right.$ and $\left.\mathrm{Si}_{3} \mathrm{~N}_{4}\right)$. One of the main results is that alumina reacts with carbon in two competitive ways; that is, the oxycarbide formation reaction and the volatilization reaction. An attempt was made to account for the interesting features of the oxycarbide formation from the chemical thermodynamic and the kinetic points of view.

$\dagger$ According to Rosenblatt ${ }^{(3)}$, evaporation and volatilization reaction are distinguished in this report in terms of whether the vapors are evolved from a single condensed phase or by reaction between more than two phases. When both processes are concerned, volatilization is used. 
This leads to the suggestion that the gaseous species such as $\mathrm{Al}_{2} \mathrm{O}, \mathrm{SiO}$ and $\mathrm{Al}$ may play an important role in the oxycarbide formation.

Measurements in I were made on pelletized samples under an argon atmosphere. A remarkable feature of such experiments is that there appears a gradient of the partial pressure of evolved gases in the pelletized samples during reaction, because it takes some time for the evolved gases to escape from the pellet. Since the intermediate compounds in the present system seem to be formed dependently on the partial pressure of $\mathrm{Al}_{2} \mathrm{O}, \mathrm{Al}$ and $\mathrm{SiO}$, it becomes desirable to obtain information on the volatilization alone; the results given in $I$ can be regarded as the results of the combined process of the volatilization and the reaction of the condensed phases with evolved gaseous species. To obtain such information, we thought that the thermal analysis in vacuum is appropriate. In the present study, we report the results of thermal analytical measurements on aluminum oxycarbides and on mixtures of alumina and carbon. To prevent samples from reacting with evolved gases, measurements were made without any pelletization of sample. These experimental conditions seem to provide useful information on whether additives act on the volatilization process or on the formation of intermediates through a solid-solid reaction.

\section{Chemical Thermodynamics of Volatilization}

The present results of thermal analyses will be compared with the solid-gas equilibrium properties in a later section. This section presents major results of the chemical thermodynamic considerations.

The volatilization in the Al-O-C system had attracted little attention untill Motzfeldt and coworkers $^{(7)}$ measured the equilibrium pressure over the mixtures of $\mathrm{Al}_{2} \mathrm{O}_{3}, \mathrm{Al}_{4} \mathrm{O}_{4} \mathrm{C}$ and $\mathrm{C}$ and of $\mathrm{Al}_{4} \mathrm{O}_{4} \mathrm{C}, \mathrm{Al}_{4} \mathrm{C}_{3}$ and $\mathrm{C}$, deriving the Gibbs energy change for formation of $\mathrm{Al}_{4} \mathrm{O}_{4} \mathrm{C}$. Their study makes it possible to calculate the solid-gas equilibrium in the Al-O-C system; for the Al-O binary system, Yanagida and Kröger $^{(8)}$ already presented in detail the equilibrium properties. Thus, Cochrun ${ }^{(1)}$ made

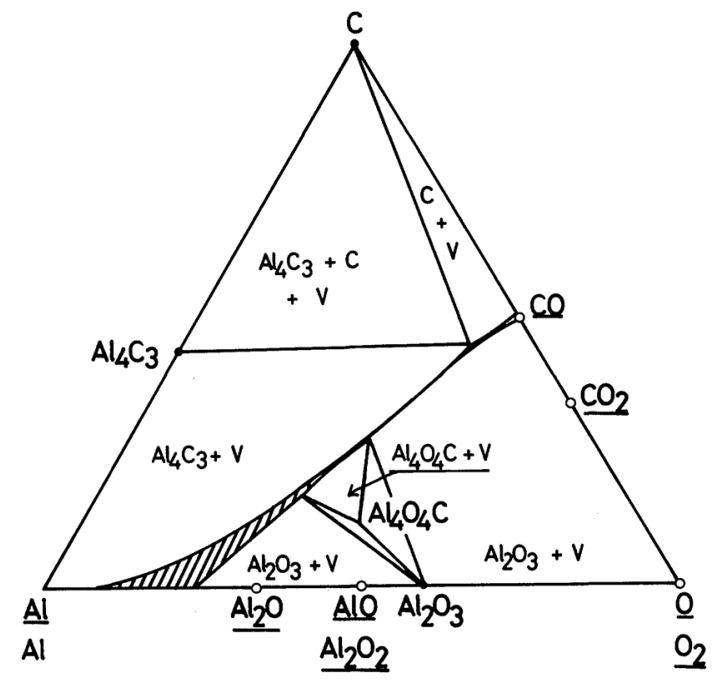

Fig. 1 The solid-gas phase relations in the Al-O-C system at $1800 \mathrm{~K}$ and $134 \mathrm{~Pa}$. The vapors (indicated by hatched area) consist mainly of $\mathrm{CO}, \mathrm{CO}_{2}$ and $\mathrm{O}_{2}$ in the oxygen rich region, and of $\mathrm{CO}, \mathrm{Al}$ and $\mathrm{Al}_{2} \mathrm{O}$ in the aluminum rich region.

an extensive analysis on the chemical thermodynamic nature of the reduction of alumina with carbon by applying the ideal association model to the aluminum-carbon liquid alloy and to the oxycarbide melts. Simpo and Goto ${ }^{(9)}$ have also made similar calculations including effects of the presence of other oxides.

These earlier investigations placed an emphasis upon the high temperature behavior of mixtures consisting initially of alumina and carbon. Here, we will focus our attention on the evaporation of the aluminum oxycarbides, and the solid-gas phase relation in the $\mathrm{Al}_{2} \mathrm{O}_{3}$ $\mathrm{Al}_{4} \mathrm{C}_{3}$ pseudobinary system. Figure 1 shows the solid-gas equilibria in the $\mathrm{Al}-\mathrm{O}-\mathrm{C}$ system at $1800 \mathrm{~K}$ and $134 \mathrm{~Pa}(\log (P / 101325 \mathrm{~Pa})=$ $-2.88)$. In the oxygen-rich region, the vapors consist mainly of $\mathrm{CO}, \mathrm{CO}_{2}$ and $\mathrm{O}_{2}$. However, in the aluminum-rich region (in reducing atmosphere), such vapor species as $\mathrm{Al}_{2} \mathrm{O}, \mathrm{Al}$ and $\mathrm{CO}$ are predominant. The composition of vapor in equilibrium with solid compounds depends on temperature and pressure as well as the thermodynamic nature of the solid compounds.

The pressure-composition diagram in the $\mathrm{Al}_{2} \mathrm{O}_{3}-\mathrm{Al}_{4} \mathrm{C}_{3}$ pseudobinary system at $1800 \mathrm{~K}$ is presented in Fig. 3; a part of the results at 
$2100 \mathrm{~K}$ was already reported in $\mathrm{I}$.

Figure 3 shows that the tetroxycarbide evaporates incongruently; the remaining phase is $\alpha$ alumina. The evaporation of $\mathrm{Al}_{4} \mathrm{O}_{4} \mathrm{C}$ can be thus written as the following reactions;

$$
\mathrm{Al}_{4} \mathrm{O}_{4} \mathrm{C}(\mathrm{s})=\mathrm{Al}_{2} \mathrm{O}_{3}(\mathrm{~s})+2 \mathrm{Al}(\mathrm{g})+\mathrm{CO}(\mathrm{g}),
$$

and

$$
\mathrm{Al}_{4} \mathrm{O}_{4} \mathrm{C}(\mathrm{s})=0.5 \mathrm{Al}_{2} \mathrm{O}_{3}(\mathrm{~s})+1.5 \mathrm{Al}_{2} \mathrm{O}(\mathrm{g})+\mathrm{CO}(\mathrm{g}) \text {. }
$$

When pure $\mathrm{Al}_{4} \mathrm{O}_{4} \mathrm{C}$ decomposes into alumina and gaseous species $\left(\mathrm{Al}, \mathrm{Al}_{2} \mathrm{O}\right.$ and $\left.\mathrm{CO}\right)$, the partial pressures of each species and then the total pressure can be obtained under the stoichiometric condition. This corresponds to the point $\mathrm{P}$ in the figure. When $\mathrm{Al}_{4} \mathrm{O}_{4} \mathrm{C}$ decomposes completely at this point, the mass ratio of the developed $\mathrm{Al}_{2} \mathrm{O}_{3}$ to the intial $\mathrm{Al}_{4} \mathrm{O}_{4} \mathrm{C}$ can be evaluated as 0.43 at $1800 \mathrm{~K}$. This ratio decreases with increasing temperature, since the content of $\mathrm{Al}_{2} \mathrm{O}$ in vapors increases (compare eq. (1) with eq. (2)).

In order to examine the evaporation of the monoxycarbide thermodynamically, we need its Gibbs energy of formation. Unfortunately, no reliable experimental results have been reported so far, although Cox and Pidgeon ${ }^{(10)}$ reported experimental values on the basis of a small change in DTA curve. As we discussed in $\mathrm{I}, \mathrm{Al}_{2} \mathrm{OC}$ can be stabilized by forming solid

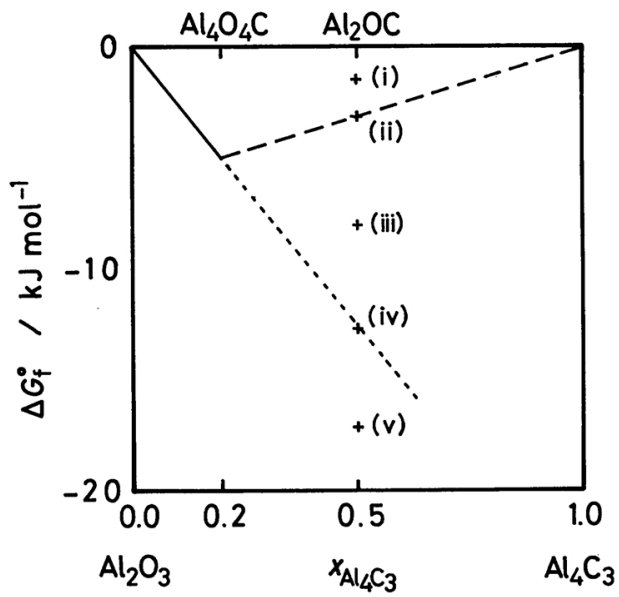

Fig. 2 Assumed Gibbs energy of formation of $\mathrm{Al}_{2} \mathrm{OC}$ from oxide and carbide at $1800 \mathrm{~K}$. Case (i) means that $\mathrm{Al}_{4} \mathrm{O}_{4} \mathrm{C}$ is stable, $\mathrm{Al}_{2} \mathrm{OC}$ being unstable, (iii) both stable and (v) $\mathrm{Al}_{4} \mathrm{O}_{4} \mathrm{C}$ unstable $\mathrm{Al}_{2} \mathrm{OC}$ stable. solutions with the isostructural compounds such as aluminum nitride and/or silicon carbide. The chemical potential of $\mathrm{Al}_{2} \mathrm{OC}$, therefore, depends on the nature of the solid solution; $\mathrm{Al}_{2} \mathrm{OC}$ is more stabilized in solution with $\mathrm{AlN}$ than in solution with SiC. Unfortunately, we do not know the quantitative thermodynamic properties of $\mathrm{Al}_{2} \mathrm{OC}$ in solid solutions. Here, we examine qualitatively the evaporation of $\mathrm{Al}_{2} \mathrm{OC}$ with various estimates for its chemical
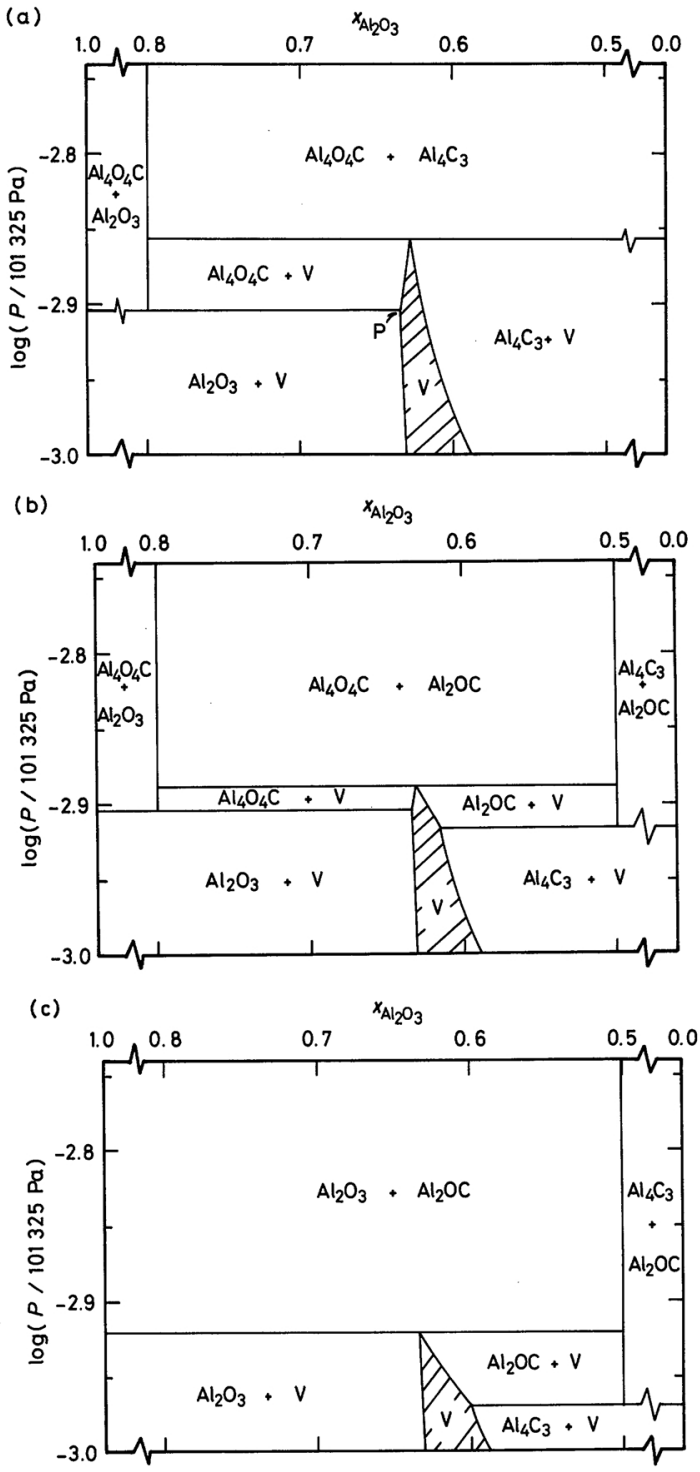

Fig. 3 The pressure-composition diagram in the $\mathrm{Al}_{2} \mathrm{O}_{3}-\mathrm{Al}_{4} \mathrm{C}_{3}$ pseudobinary system at $1800 \mathrm{~K}$. For $\mathrm{Al}_{2} \mathrm{OC}$, (a) corresponds to case (i) in Fig. 2, (b) to (iii) and (c) to (v). 
potential. These are presented in Fig. 2; the Gibbs energy change for formation of the oxycabides from alumina and carbide are plotted as a function of composition. Motzfeldt and Sanberg ${ }^{(7)}$ found that in the $\mathrm{Al}_{2} \mathrm{O}_{3}-\mathrm{Al}_{4} \mathrm{C}_{3}$ system, $\mathrm{Al}_{4} \mathrm{O}_{4} \mathrm{C}$ is stable, whereas $\mathrm{Al}_{2} \mathrm{OC}$ is thermodynamically unstable at high temperatures. This can be represented by the case (i) in Fig. 2. Our estimate for $\mathrm{Al}_{2} \mathrm{OC}$ in solution with $\mathrm{SiC}$ given in I corresponds to the case (iv). When $\mathrm{Al}_{2} \mathrm{OC}$ is stabilized by nitride, its stabilization energy is quite large; this may correspond to the case (v). The data reported by Cox and Pidgeon $^{(10)}$ may correspond to the extreme case of (v).

The pressure-composition diagram in the $\mathrm{Al}_{2} \mathrm{O}_{3}-\mathrm{Al}_{4} \mathrm{C}_{3}$ pseudobinary system at $1800 \mathrm{~K}$ with $\mathrm{Al}_{2} \mathrm{OC}$ included are presented in Fig. 3(b) and (c) for the cases (iii) and (v), respectively. Except for the case (i) represented by Fig. 3(a), $\mathrm{Al}_{2} \mathrm{OC}$ evaporates incongruently, and aluminum carbide (or graphite) remains in the condensed phase. This can be explained as follows. At first, we can consider the decomposition of $\mathrm{Al}_{2} \mathrm{OC}$ in the following way;

$$
\mathrm{Al}_{2} \mathrm{OC}=\mathrm{Al}_{2} \mathrm{O}(\mathrm{g})+\mathrm{C}(\mathrm{s})
$$

and

$$
\mathrm{Al}_{2} \mathrm{OC}=2 \mathrm{Al}(\mathrm{g})+\mathrm{CO}(\mathrm{g}) .
$$

Then the carbide can be formed in the pressure region where $\mathrm{Al}_{4} \mathrm{C}_{3}$ is stable;

$$
3 \mathrm{C}(\mathrm{s})+4 \mathrm{Al}(\mathrm{g})=\mathrm{Al}_{4} \mathrm{C}_{3} \text {. }
$$

Figure 3 shows that with increasing stability of the $\mathrm{Al}_{2} \mathrm{OC}$ phase, the vaporization by eq. (4) becomes favorable, and correspondingly the total decomposition pressure decreases.

\section{Experimental}

\section{Materials}

A sample of $\mathrm{Al}_{4} \mathrm{O}_{4} \mathrm{C}$ was prepared from mixtures of $\alpha$-alumina and aluminum carbide. Since it was not easy to obtain pure $\mathrm{Al}_{4} \mathrm{O}_{4} \mathrm{C}$ in a large amount from powder mixtures, we collected needle-like crystals of $\mathrm{Al}_{4} \mathrm{O}_{4} \mathrm{C}$ out of the reaction products. $\mathrm{X}$-ray diffractometric results on the sample have, however, revealed that the sample was contaminated by a small amount of $\alpha$-alumina; this was roughly evaluated as several per cent from the peak hight ratio of appropriate diffraction lines.

A sample of $\mathrm{Al}_{2} \mathrm{OC}$ was prepared from mixtures of alumina, graphite and 5 mass $\%$ of silicon nitride. This sample was of a solid solution with a few per cent of $\mathrm{SiC}$ and $\mathrm{AlN}$, and its crystal structure is of $\alpha$-type (high temperature normal $2 H$ structure $)^{(11)}$. In addition to solutes of $\mathrm{SiC}$ and $\mathrm{AIN}$, the sample was found from X-ray diffractometry to contain a small amount of $\mathrm{Al}_{4} \mathrm{Si}_{2} \mathrm{C}_{5}$ and graphite.

The volatilization was investigated on mixtures of alumina and carbides $\left(\mathrm{Al}_{4} \mathrm{C}_{3}\right.$ and $\left.\mathrm{SiC}\right)$ and also of alumina and graphite. In the former case, the mole ratio of oxide to carbide was chosen as $m\left(\mathrm{Al}_{2} \mathrm{O}_{3}\right) / m\left(\mathrm{Al}_{4} \mathrm{C}_{3}\right)=1$, and $m\left(\mathrm{Al}_{2} \mathrm{O}_{3}\right) / m(\mathrm{SiC})=1 / 3$. In the latter case, the mole ratio of $m\left(\mathrm{Al}_{2} \mathrm{O}_{3}\right) / m(\mathrm{C})=1 / 3$ was adopted, and effects of additives such as $\left(\mathrm{Fe}_{2} \mathrm{O}_{3}+3 \mathrm{C}\right)$, $\mathrm{Si}_{3} \mathrm{~N}_{4}$ and $\mathrm{SiC}$ in 5 mass \% were also examined; for the case of iron oxide addition, measurements were made on two additional samples containing 10 and 20 mass $\%$ of $\left(\mathrm{Fe}_{2} \mathrm{O}_{3}+3 \mathrm{C}\right)$, respectively. We measured also on mixtures of alumina, silica (or mullite), iron oxide and carbon; the mole ratio of oxide to carbon was fixed so that $m(\mathrm{O})=m(\mathrm{C})$.

Measurements were made without any pelletization of sample with the aims described in Introduction.

\section{Thermal analysis}

Measurements were made with a thermoanalyzer of Mettler (No. 195). A heating element was of tungsten fabricated in a hexagonal tube form. A rod made of tungsten rhenium alloy was used for supporting a sample assembly. This rod was also used as a part of thermocouples for measuring temperature as well as DTA output between sample and reference; the other parts of thermocouples made of tungsten wire were welded to two, separate, holding plates. Since the present samples contained carbon, it is necessary to prevent the tungsten-rhenium alloy from reacting with carbon. For this purpose, we tried to adopt two schemes of sample assembly; one (denoted as (a)) is of double crucible system, and the other (b) is of crucible-plate system. In the former, 
samples were loaded into an alumina crucible that was placed in a tungsten crucible. In this case, the reaction between alumina and tungsten is of primary concern. A preliminary experiment showed that this reaction indeed occurred and caused an endothermic effect on the base line of the DTA curve. In the latter scheme of holding sample, samples were loaded into a graphite crucible which was placed on a tungsten plate. In such a case, the reaction between tungsten and graphite becomes crucial. An experiment showed that this reaction occurred, but the drift of the base line was small. The crucible-plate scheme was, therefore, adopted, except for the mixtures of $\mathrm{Al}_{2} \mathrm{O}_{3}$, $\mathrm{SiO}_{2}, \mathrm{Fe}_{2} \mathrm{O}_{3}$ and $\mathrm{C}$. Use was made of graphite powder as the reference for DTA measurements.

Measurements were made in vacuum; this is, in addition to the reason described in Introduction, to prevent tungsten elements from being attacked by evolved $\mathrm{CO}$ gas. Note that the sensor of pressure is placed in a cold zone between the high temperature furnace and the evacuating system, and is, therefore, insensitive to the recondensable vapor species. The heating rate was fixed at $4 \mathrm{~K} / \mathrm{min}$ throughout the experiments.

\section{Results and Comparison with Equilibrium Properties}

Table 1 summarizes the weight change after experiments. The negative values of the final weight in series 4 indicate that side reactions of samples with the alumina crucible occurred during experiments. Samples in this series came out of the crucible, before the volatilization reaction was completed; this was checked by abrupt change in weight. Thus, the temperature and the weight loss ratio at that time were also listed in Table 1. Small abrupt changes were detected frequently for almost all samples; this is due mainly to the corresponding changes in pressure. In such cases, there appeared an anomalous change in the differential weight loss curve because of inappropriate differentiation (see Figs. 4 to 7 ).

\section{Aluminum oxycarbides, $\mathrm{Al}_{4} \mathrm{O}_{4} \mathrm{C}$ and $\mathrm{Al}_{2} \mathrm{OC}$}

Results of the thermal analytical measurement on the $\mathrm{Al}_{4} \mathrm{O}_{4} \mathrm{C}$ sample are given in Fig. 4(a), which shows weight loss (TG), differential weight loss (DTG), thermal effect (DTA), and pressure $(\mathrm{P})$ as a function of temperature.

Weight of $\mathrm{Al}_{4} \mathrm{O}_{4} \mathrm{C}$ began to decrease above

Table 1 Summaries of thermogravimetric results; (a) sample holding scheme is double crucible one, (b) being plate/crucible one. For weight ratio in parrentheses in series 4 , see text.

\begin{tabular}{|c|c|c|c|c|c|}
\hline \multirow[b]{2}{*}{ Series } & \multirow[b]{2}{*}{ Sample and holding scheme } & \multicolumn{3}{|c|}{ Weight change } & \multirow[b]{2}{*}{$\begin{array}{l}\text { ratio } \\
\left(W_{\mathrm{i}}-W_{\mathrm{f}}\right) / W_{\mathrm{i}}\end{array}$} \\
\hline & & & $\begin{array}{l}\text { initial } \\
W_{i} / \mathrm{mg}\end{array}$ & $\begin{array}{c}\text { final } \\
W_{\mathrm{f}} / \mathrm{mg}\end{array}$ & \\
\hline $1-\mathrm{a}$ & $\mathrm{Al}_{4} \mathrm{O}_{4} \mathrm{C}$ & (b) & 22.8 & 6.6 & 0.711 \\
\hline $\mathrm{b}$ & $\mathrm{Al}_{2} \mathrm{OC}$ & (b) & 33.6 & 2.7 & 0.920 \\
\hline $2-\mathrm{a}$ & $\mathrm{Al}_{2} \mathrm{O}_{3}+3 \mathrm{C}$ & (b) & 36.9 & 16.1 & 0.564 \\
\hline $\mathrm{b}$ & $\left(\mathrm{Al}_{2} \mathrm{O}_{3}+3 \mathrm{C}\right)+\mathrm{SiC}\langle 5$ mass $\%\rangle$ & (b) & 19.6 & 6.0 & 0.694 \\
\hline c & $\left(\mathrm{Al}_{2} \mathrm{O}_{3}+3 \mathrm{C}\right)+\mathrm{Si}_{3} \mathrm{~N}_{4}\langle 5$ mass $\%\rangle$ & (b) & 23.4 & 7.4 & 0.684 \\
\hline d & $\left(\mathrm{Al}_{2} \mathrm{O}_{3}+3 \mathrm{C}\right)+\left(\mathrm{Fe}_{2} \mathrm{O}_{3}+3 \mathrm{C}\right)\langle 5$ mass $\%\rangle$ & (b) & 20.9 & 5.1 & 0.756 \\
\hline e & $\left(\mathrm{Al}_{2} \mathrm{O}_{3}+3 \mathrm{C}\right)+\left(\mathrm{Fe}_{2} \mathrm{O}_{3}+3 \mathrm{C}\right)\langle 10$ mass $\%\rangle$ & (b) & 19.7 & 2.2 & 0.888 \\
\hline f & $\left(\mathrm{Al}_{2} \mathrm{O}_{3}+3 \mathrm{C}\right)+\left(\mathrm{Fe}_{2} \mathrm{O}_{3}+3 \mathrm{C}\right)\langle 20$ mass $\%\rangle$ & (b) & 18.2 & 1.9 & 0.896 \\
\hline $3-\mathbf{a}$ & $\mathrm{Al}_{2} \mathrm{O}_{3}+\mathrm{Al}_{4} \mathrm{C}_{3}$ & (b) & 19.0 & 0.2 & 0.989 \\
\hline b & $\mathrm{Al}_{2} \mathrm{O}_{3}+\mathrm{SiC}$ & (b) & 22.2 & 5.5 & 0.752 \\
\hline $4-\mathbf{a}$ & $2 \mathrm{Al}_{2} \mathrm{O}_{3}+3 \mathrm{SiO}_{2}+12 \mathrm{C}$ & (a) & 56.3 & -0.1 & $1.002(0.86$ at $1908 \mathrm{~K})$ \\
\hline b & $3 \mathrm{Al}_{2} \mathrm{O}_{3}-2 \mathrm{SiO}_{2}+13 \mathrm{C}\left(\mathrm{M}^{*}\right)$ & (a) & 61.5 & -5.5 & $1.089(0.86$ at $1908 \mathrm{~K})$ \\
\hline c & $\mathrm{M}+\mathrm{AF}<5$ mass $\%\rangle^{* *}$ & (a) & 56.2 & -3.9 & $1.069(0.85$ at $1898 \mathrm{~K})$ \\
\hline d & $\mathrm{M}+\mathrm{AF}\langle 10 \text { mass } \%\rangle^{* *}$ & (a) & 46.3 & -2.9 & $1.063(0.76$ at $1853 \mathrm{~K})$ \\
\hline e & $\mathrm{M}+\mathrm{AF}\langle 20 \text { mass } \%\rangle^{* *}$ & (a) & 51.1 & -1.4 & $1.027(0.67$ at $1813 \mathrm{~K})$ \\
\hline f & $\mathrm{M}+\mathrm{AF}\langle 50 \text { mass } \%\rangle^{* *}$ & (a) & 56.6 & -6.8 & $1.120(0.97$ at $1913 \mathrm{~K})$ \\
\hline
\end{tabular}

* $\mathrm{M}$ denotes mixture of $\left(3 \mathrm{Al}_{2} \mathrm{O}_{3}-2 \mathrm{SiO}_{2}+13 \mathrm{C}\right)$.

** AF; mixture of $\left(0.5 \mathrm{Al}_{2} \mathrm{O}_{3}+0.5 \mathrm{Fe}_{2} \mathrm{O}_{3}+3 \mathrm{C}\right)$ 

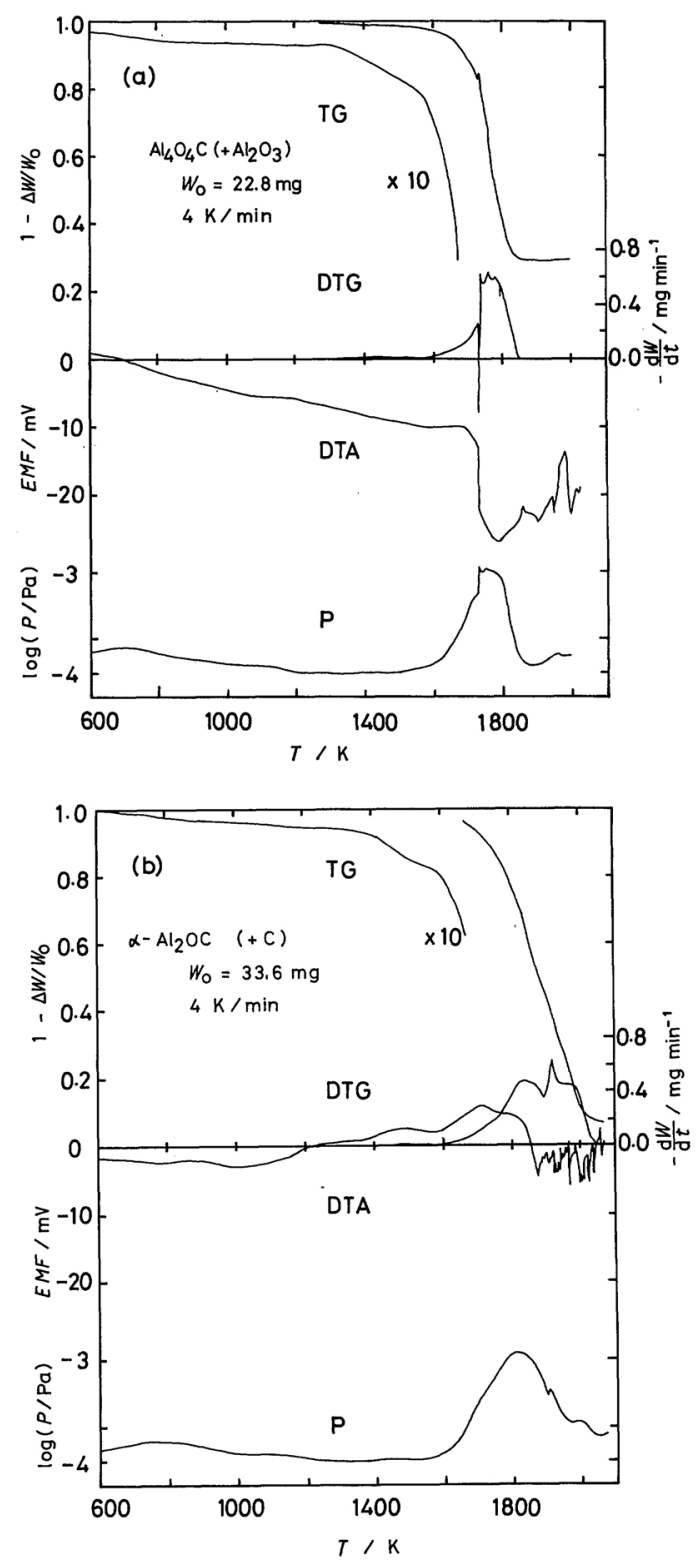

Fig. 4 Results of thermal analysis on oxycarbides. (a) aluminum tetroxycarbide contaminated with a small amount of alumina; (b) $\alpha$-aluminum monoxycarbide contaminated with a small amount of graphite.

$1300 \mathrm{~K}$, and then a significant evaporation took place around $1570 \mathrm{~K}$. The evaporation ceased completely at $1800 \mathrm{~K} ; 29$ mass \% of the sample remained unevaporated after being heated up to $2000 \mathrm{~K}$. X-ray diffractometric results show that the remains are $\alpha$-alumina. These features correspond well to those of the pressure curve and also of the DTA curve showing an endothermic effect; large drifts of DTA curve above $1850 \mathrm{~K}$ are due to the reaction between the graphite crucible and the tungsten plate. The weight ratio of the remaining $\alpha-\mathrm{Al}_{2} \mathrm{O}_{3}$ to the initial $\mathrm{Al}_{4} \mathrm{O}_{4} \mathrm{C}$ was found to be 0.29 ; this is somewhat smaller than the thermodynamic estimate of 0.43 given in Section II. This may be due partly to uncertainties of the thermodynamic data used and partly to some kinetic factor in the volatilization process. Whichever it is, the fact that the remaining amount is less than the estimate means that the vapors contained $\mathrm{Al}(\mathrm{g})$ in a less amount than the evaluated one; in other words, the decomposition of $\mathrm{Al}_{4} \mathrm{O}_{4} \mathrm{C}$ took place mainly as given by eq. (2).

The results on the aluminum monoxycarbide, $\mathrm{Al}_{2} \mathrm{OC}$, is given in Fig. 4(b). The evaporation started slightly from $1400 \mathrm{~K}$ and significantly took place from 1600 to $2000 \mathrm{~K}$. Difference in evaporation between $\mathrm{Al}_{2} \mathrm{OC}$ and $\mathrm{Al}_{4} \mathrm{O}_{4} \mathrm{C}$ can be seen both in the temperature region and in the manner. First, $\mathrm{Al}_{2} \mathrm{OC}$ evaporated at higher temperatures than did $\mathrm{Al}_{4} \mathrm{O}_{4} \mathrm{C}$. Second, the evaporation of $\mathrm{Al}_{2} \mathrm{OC}$ is essentially congruent; the remains in a very small amount were found to be graphite and $\mathrm{SiC}$.

It seems interesting to compare the present results on $\mathrm{Al}_{2} \mathrm{OC}$ with the chemical thermodynamic considerations summarized in Fig. 3. There can be two possible explanations for the observed congruent evaporation of $\mathrm{Al}_{2} \mathrm{OC}$. The first is the chemical thermodynamic one; this regards the congruent evaporation as a result of the extreme stability of $\mathrm{Al}_{2} \mathrm{OC}$ as expressed by the extreme case of (v) in Fig. 2. Note that the present sample is highly stabilized by the aluminum nitride and silicon carbide. The second explanation is the kinetic one. This ascribes the observed congruent evaporation to some kinetic reasons, by which the carbide is prevented from being formed. At the experimental pressures $\left(10^{-4}\right.$ to $\left.10^{-3} \mathrm{~Pa}\right)$, the gaseous mixture is in equilibrium with carbon. Thus, $\mathrm{Al}_{2} \mathrm{OC}$ can evaporate forming no aluminum carbide but carbon; this process is quite close to the congruent evaporation. At present, the absence of the reliable thermodynamic data of $\mathrm{Al}_{2} \mathrm{OC}$ makes it impossible to obtain further 
understanding on the evaporation of $\mathrm{Al}_{2} \mathrm{OC}$.

We found a peculiar behavior of $\mathrm{Al}_{2} \mathrm{OC}$ in the DTA curve which showed an exothermal effect at the early stage of its evaporation. At present we have no reasonable explanation for it. It should be here noted that in many cases, the DTA output in the present system is quite weakened despite a strongly endothermic volatilization process.

\section{Alumina and carbon; effects of additives}

The results on the mixture of alumina and carbon are given in Fig. 5. When the mixture was heated, the volatilization reaction occurred from $1450 \mathrm{~K}$ and became significant in the temperature region from 1600 to $1950 \mathrm{~K}$. Above

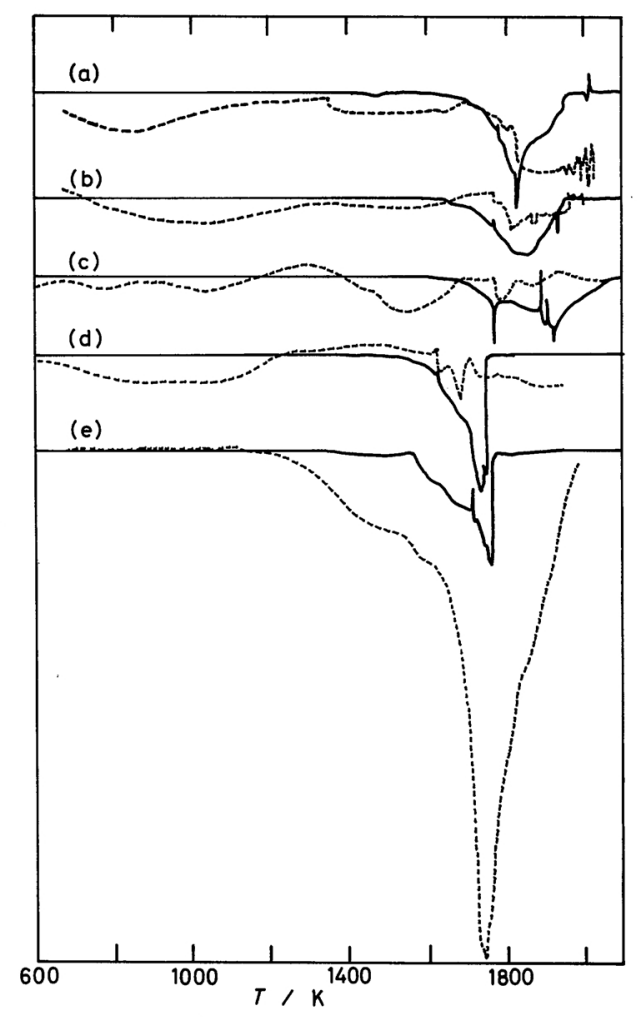

Fig. 5 Results of differential weight loss (DTG, solid line) and differential thermal analysis (DTA, broken line) on alumina with carbon. Lower direction indicates weight loss and endothermic, respectively. (a) alumina with carbon alone; (b) added by 5 mass \% of $\beta$-SiC; (c) added by 5 weight per cent of $\mathrm{Si}_{3} \mathrm{~N}_{4}$; (d) added by 5 mass $\%$ of $\left(\mathrm{Fe}_{2} \mathrm{O}_{3}+\mathrm{C}\right)$; (e) added by 10 mass $\%$ of $\left(\mathrm{Fe}_{2} \mathrm{O}_{3}+\mathrm{C}\right)$; (f) added by 20 mass $\%$ of $\left(\mathrm{Fe}_{2} \mathrm{O}_{3}+\mathrm{C}\right)$. that temperature the volatilization ceased, although about a half of sample still remained. After experiment, the remaining sample was white at first sight; however, after being ground, it became black. The existence of graphite, in addition to unreacting alumina, was confirmed by X-ray diffractometry. This means that the volatilization was prevented at the final stage although both alumina and graphite still remained. This is due apparently to a poor physical contact between reactants as a result of the significant volatilization.

When 5 mass $\%$ of SiC was added to the mixture of alumina and carbon, the volatilization reaction took place essentially in the same manner.

The addition of $\mathrm{Si}_{3} \mathrm{~N}_{4}$ made the DTG peak broad toward the high temperature region (Fig. 5(c)). This feature is quite similar to that of $\mathrm{Al}_{2} \mathrm{OC}$ (Fig. 5(b)). In addition, a broad endothermic DTA peak was found, before the weight started decreasing. It is, therefore, highly likely that before the volatilization reaction started, the $\mathrm{Al}_{2} \mathrm{OC}$ formation reaction might occur. This is consistent with the observation and the discussion on the formation of $\mathrm{Al}_{2} \mathrm{OC}$ given in $\mathrm{I}$.

In the case of $\mathrm{Fe}_{2} \mathrm{O}_{3}$ addition (Fig. 5(d)), the volatilization reaction was enhanced in contrast to the case of $\mathrm{Si}_{3} \mathrm{~N}_{4}$ addition; the starting temperature of the volatilization reaction was lowered and the shape of the DTG curve was sharpened. It is worthy to note that the features of the weight loss curve are almost the same among the samples with various contents of $\mathrm{Fe}_{2} \mathrm{O}_{3}$ (compare Fig. 5(d) and (e)). This strongly suggests a catalytic effect of iron on the volatilization reaction between alumina and carbon. Since it is well established that carbon dissolved in liquid iron shows the higher reactivity than does the solid carbon, it would be likely that iron exists as liquid metal containing carbon at the volatilization stage of alumina. Although the DTA curve did not indicate clearly a prior reduction of iron oxides, the large endothermic peak implies that liquid was formed in the sample, because the anomalously large peak probably resulted from a change in manner of heat conduction from the sample to the DTA sensor through the crucible. 
The catalytic activity of iron in turn shows that the volatilization reaction between alumina and carbon has some kinetic barrier.

\section{Alumina and carbide}

The results on the mixtures of alumina and $\mathrm{Al}_{4} \mathrm{C}_{3}$ and of alumina and $\mathrm{SiC}$ are given in Fig. 6. The mixture of alumina and $\mathrm{Al}_{4} \mathrm{C}_{3}$ volatilized at lower temperatures than did that of alumina and carbon, but did in the same temperature region as that of alumina, iron oxide and carbon. An important observation is that the mixture of alumina and aluminum carbide almost completely volatilized. This indicates, under the stoichiometric condition, that the major volatilization reaction may take place as

$$
\mathrm{Al}_{2} \mathrm{O}_{3}+\mathrm{Al}_{4} \mathrm{C}_{3}=6 \mathrm{Al}(\mathrm{g})+3 \mathrm{CO}(\mathrm{g}) .
$$

Note that among the gaseous aluminum species, $\mathrm{Al}(\mathrm{g})$ is predominant. It is, therefore, likely that the formation of $\mathrm{Al}_{4} \mathrm{O}_{4} \mathrm{C}$ did not take place and that the volatilization occurred as a result of direct reaction between alumina and $\mathrm{Al}_{4} \mathrm{C}_{3}$. This seems to be consistent with the thermodynamic considerations; under the experimental pressure (about $10^{-4} \mathrm{~Pa}$ ), aluminum oxycarbides are not stable against the volatiliza-

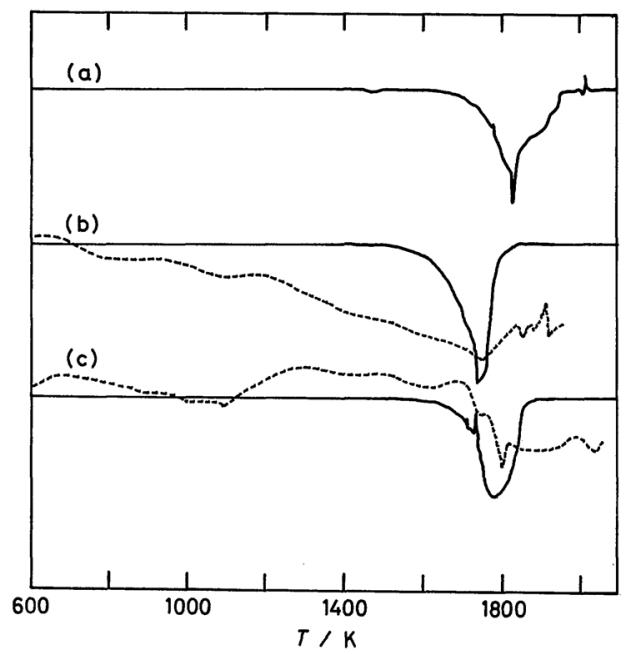

Fig. 6 Results of differential weight loss (DTG, solid line) and differential thermal analysis (DTA, broken line) on alumina with carbides. Lower direction indicates weight loss and endothermic, respectively. (a) alumina with carbon alone, $W_{0}=36.9 \mathrm{mg}$. (b) with aluminum carbide; (c) with silicon carbide. tion, and the vapors in equilibrium with $\mathrm{Al}_{4} \mathrm{C}_{3}$ or graphite consist mainly of $\mathrm{Al}(\mathrm{g})$ and $\mathrm{CO}(\mathrm{g})$ under that pressure.

The mixture of alumina and $\mathrm{SiC}$ volatilized at higher temperatures than did that of alumina and $\mathrm{Al}_{4} \mathrm{C}_{3}$. Note also that a substantial amount of $\mathrm{SiC}$ remained unreacted. These may be due to the less volatile nature of $\mathrm{SiC}$ and the relatively low stability of $\mathrm{Si}$ vapor $^{(12)}$. The volatilization reaction of alumina and silicon carbide can be thus written as

$$
\begin{aligned}
& \mathrm{Al}_{2} \mathrm{O}_{3}+1.5 \mathrm{SiC} \\
& =2 \mathrm{Al}(\mathrm{g})+1.5 \mathrm{SiO}(\mathrm{g})+1.5 \mathrm{CO}(\mathrm{g}) .
\end{aligned}
$$

Under the present experimental condition, $\mathrm{Al}_{2} \mathrm{O}(\mathrm{g})$ may not contribute in view of the discussion above, whereas $\mathrm{SiO}(\mathrm{g})$ may be the major species among the gaseous silicon compounds $^{(13)}$. From this equation, we can calculate the weight ratio of the remaining SiC to the initial mixture to be 0.27 without taking into account the evaporation of $\mathrm{SiC}$. This value is well consistent with the experimental value of 0.22 .

\section{Alumina, silica and carbon}

Figure 7 summarizes the results of the differential thermogravimetry on mixtures of alumina, silica, and carbon and its modifications. This series was measured with the alumina crucible - tungusten crucible holding scheme.

The results on $\left(2 \mathrm{Al}_{2} \mathrm{O}_{3}+3 \mathrm{SiO}_{2}+12 \mathrm{C}\right)$ shows that the volatilization reaction took place in two stages. The first one corresponds to the volatilization reaction of silica with carbon;

$$
\mathrm{SiO}_{2}+\mathrm{C}=\mathrm{SiO}(\mathrm{g})+\mathrm{CO}(\mathrm{g}),
$$

the second being that of alumina with carbon;

$$
\mathrm{Al}_{2} \mathrm{O}_{3}+3 \mathrm{C}=2 \mathrm{Al}(\mathrm{g})+3 \mathrm{CO}
$$

and

$$
\mathrm{Al}_{2} \mathrm{O}_{3}+2 \mathrm{C}=\mathrm{Al}_{2} \mathrm{O}(\mathrm{g})+3 \mathrm{CO}(\mathrm{g}) .
$$

Mixture of mullite and carbon $\left(3 \mathrm{Al}_{2} \mathrm{O}_{3}\right.$. $2 \mathrm{SiO}_{2}+13 \mathrm{C}$ ) showed also the two stage volatilization. The first one in this case can be given as

$$
\begin{aligned}
3 \mathrm{Al}_{2} \mathrm{O}_{3} \cdot 2 \mathrm{SiO}_{2} & +2 \mathrm{C} \\
& =3 \mathrm{Al}_{2} \mathrm{O}_{3}+\mathrm{SiO}(\mathrm{g})+\mathrm{CO}(\mathrm{g}) .
\end{aligned}
$$

The coexistence of alumina and mullite at the 
(a)

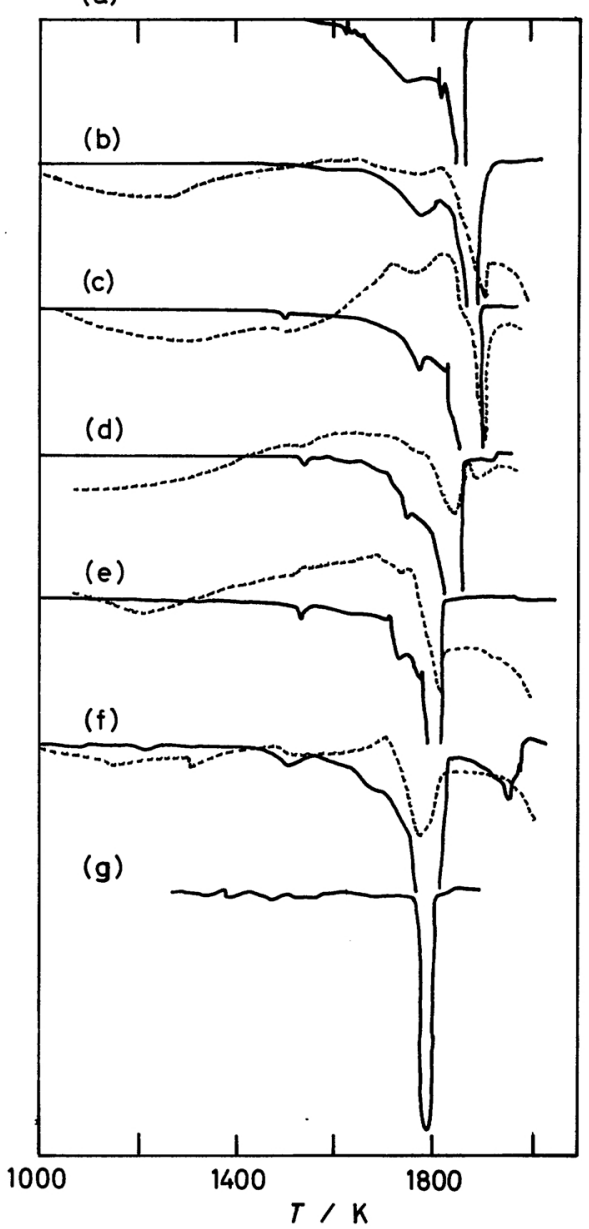

Fig. 7 Results of differential weight loss (DTG, solid line) and differential thermal analysis (DTA, broken line) on alumina, silica and iron oxide with carbon: Lower direction indicates weight loss and endothermic, respectively. $\mathrm{AS} ; 2 \mathrm{Al}_{2} \mathrm{O}_{3}+3 \mathrm{SiO}_{2}+12 \mathrm{C}$, $\mathrm{M} ; 3 \mathrm{Al}_{2} \mathrm{O}_{3}-2 \mathrm{SiO}_{2}+13 \mathrm{C}, \mathrm{AF} ; \mathrm{Al}_{2} \mathrm{O}_{3}+\mathrm{Fe}_{2} \mathrm{O}_{3}+6 \mathrm{C}$. (a) AS; (b) $\mathrm{M}$; (c) $\mathrm{M}(95$ mass $\%)+\mathrm{AF}(5$ mass $\%)$; (d) $\mathrm{M}(90$ mass $\%)+\mathrm{AF}(10$ mass $\%)$; (e) $\mathrm{M}(80$ mass $\%)+\mathrm{AF}(20$ mass $\%)$; (f) $\mathrm{M}(50$ mass $\%)+\mathrm{AF}(50$ mass $\%$; (b) AF.

first stage was confirmed by X-ray diffractometry on the sample in this stage. The weight loss at the end of the first stage was about 0.23 , which is consistent with the stoichiometric considerations based on the above equation. The volatilization of silica component in mullite was apparently retarded, when compared with silica in mixtures. This can be reasonably interpreted as the stabilization of silica in mullite.

Additions of iron component again gave rise to the enhancement of the volatilization reaction. Note also that the feature of two-stage volatilization tends to disappear with addition of iron.

\section{Discussion}

\section{Oxycarbide formation mechanism}

In the reaction of alumina with carbon, the oxycarbide formation reaction and the volatilization reaction take place competitively. This gave rise to some controversy on the mechanism of the oxycarbide formation; that is, a direct solid-solid reaction versus an "evaporate-condensate" mechanism. The former was first proposed by Cox and Pidgeon ${ }^{(10)}$; they rejected the latter mechanism, because the evaluated pressures of suboxides are, in their calculation, extremely low compared with the pressures observed in the differential thermal analysis. Recently, however, Klug et al. ${ }^{(14)}$ have shown that the mass transfer due to the "evaporate-condensate" mechanism becomes actually predominant at higher temperatures than about $1770 \mathrm{~K}$, whereas below that temperature the rather slow diffusion in solids controlls the reaction. In $\mathrm{I}$, we also suggested that $\mathrm{Al}_{4} \mathrm{O}_{4} \mathrm{C}$ can be usually formed from vapors. The present results confirms that the volatilization in the Al-O-C system indeed becomes significant above $1800 \mathrm{~K}$ under vacuum. Furthermore, the following points should be noticed.

(1) Although $\mathrm{Al}_{4} \mathrm{O}_{4} \mathrm{C}$ evaporates at lower temperatures than the mixture of alumina and carbon volatilizes, there appears some overlapping temperature region; under an inert atmosphere, not in vacuum, $\mathrm{Al}_{4} \mathrm{O}_{4} \mathrm{C}$ can be formed from vapors evolved by reaction of alumina with carbon at temperatures at least higher than $1800 \mathrm{~K}$.

(2) $\mathrm{Al}_{2} \mathrm{OC}$ phase can be formed by a direct solid-solid reaction, when the nitride is present. If we assume that $\mathrm{Al}_{2} \mathrm{OC}$ was formed from vapors, we could not obtain a reasonable explanation for the fact that a small amount of nitride retarded the volatilization appreciably. The mechanism of the $\mathrm{Al}_{2} \mathrm{OC}$ formation in the 
simultaneous reduction reported in I remains uncertain, although the present results showed slight difference in the volatilization reaction between the mixture of mullite and carbon and that of alumina, silica and carbon.

\section{Volatilization in relation with blast furnace process}

To establish a new technology of aluminum blast furnace process, we need the extensive knowledge of the volatilization in the Al-O-C system in the presence of silicon or iron. The present results provided interesting features of the volatilization; that is, the volatilization reaction of aluminum compounds with carbon depends highly on the nature of carbon. Thermodynamically, the partial pressure of $\mathrm{Al}$ and $\mathrm{Al}_{2} \mathrm{O}$, especially its change with the $\mathrm{CO}$ pressure, depends on whether carbon exists as graphite or carbide. This nature can be seen in the present results on alumina with carbon and alumina with carbide. In addition, the present study revealed that the presence of iron enhanced the volatilization. This is ascribable to the high reactivity of carbon dissolved in liquid iron. We should here recall the major conclusion of our previous reports ${ }^{(2)(4)}$ that the aluminum blast furnace cannot be well operated in the simultaneous reduction of alumina and silica. This means that to establish the aluminum blast furnace process, we need to add a large amount of iron, in order to reduce the thermodynamic activity of aluminum in liquid alloy without introducing further volatile compounds. Note also that the addition of iron reduces the reaction temperature required for the alumina reduction by carbon. On the other hand, the present results exhibit the catalytic activity of iron in the volatilization reaction. It should be pointed out that under the present experimental conditions, the liquid aluminum cannot be formed stably. Therefore, we should examine how iron will act catalytically on the liquid alloy formation in the reduction of alumina with carbon preferably under a CO atmosphere.

\section{Acknowledgement}

The authors would like to thank Mr. S. Tomizawa for providing us the opportunity of using the thermoanalizer.

\section{REFERENCES}

(1) C. N. Cochrun: Metal-Slag-Gas Reactions and Processes, ed. by Z. A. Foroulis and W. W. Smeltzer, Electrochemical Soc., (1975), pp. 299316.

(2) H. Yokokawa, M. Fujishige, M. Dokiya, T. Kameyama, S. Ujiie and K. Fukuda: Trans. Japan Inst. Metals, 23 (1982), 134.

(3) G. M. Rosenblatt: Treatise on Solid State Chemistry Vol. 4 Reactivity of Solids, ed. by N. B. Hannay, Plenum, New York, (1976), pp. 165-240.

(4) M. Dokiya, M. Fujishige, T. Kameyama, H. Yokokawa, S. Ujiie, K. Fukuda and A. Motoe: Light Metals 1983, ed. by E. M. Adkins Metal. Soc. AIME, New York, (1983), pp. 651-670.

(5) M. A. Miller, L. M. Foster and C. D. Baker: U. S. Patent, 2,829,961 (April 8, 1958).

(6) G. Maruyama, T. Shiba and F. Iso: Japan Patent, 1966-10604 (June 13, 1966).

(7) K. Motzfeldt and B. Sanberg: Light Metals 1979 , ed. by W. S. Peterson, Metal. Soc. of AIME, New York, (1979), Vol. I, p. 411.

(8) H. Yanagida and F. A. Kröger: J. Am. Ceram. Soc., 51 (1968), 700.

(9) R. Simpo and S. Goto: J. Chem. Soc. Japan, (6) (1982), 997 (in Japanese).

(10) J. H. Cox and L. M. Pidgeon: Can. J. Chem., 41 (1963), 671.

(11) H. Yokokawa, M. Dokiya, M. Fujishige, T. Kameyama, S. Ujiie and K. Fukuda: J. Am. Ceram. Soc. 65 (1982), C-40.

(12) K. Motzfeldt: "Carbothermic Reduction of Alumina," presented at the ICSOBA-AIM conference "New Process in Aluminum Production," Cagliari, Sept. 26-28, 1979.

(13) W. W. Pultz and W. Heartl: Trans. Faraday Soc., 62 (1966), 2499.

(14) F. J. Klug, W. D. Pasco and M. P. Borom: J. Am. Ceram. Soc., 65 (1982), 619. 